\title{
Learning Management Strategy of Communication Studies through Blended Learning in Higher Education
}

\author{
https://doi.org/10.3991/ijim.v14i16.15725 \\ K.Y.S. Putri $\left({ }^{凶}\right)$ \\ Universitas Negeri Jakarta, Jakarta, Indonesia \\ kinkinsubarsa@unj.ac.id \\ Zulhamri Bin Abdullah \\ Universiti Putra Malaysia, Selangor, Malaysia \\ Elisabeth Nugrahaeni, Rachmat Darmawan, Latifa \\ Universitas Negeri Jakarta, Jakarta, Indonesia
}

\begin{abstract}
This study aims to identify learning management strategies on communication studies through Blended Learning in Higher Education. This study uses a quasi-experimental method with a non-equivalent control group research design. This design uses two groups, namely the experimental group and the control group. Data collection was conducted with 82 Communication Studies students in 2019, Faculty of Social Sciences, Jakarta State University. Researchers also work with ethics communication lecturers and new media lecturers. The results of this study indicate that blended learning can increase students' knowledge of ethical communication. The average pretest value of the experimental class was 55.93, and the posttest value was 81.85 . The average N-Gain in both the experimental class and the control class falls into the medium category. The average results of the N-Gain experimental class were higher at $0.56 \mathrm{com}$ pared to the control class at 0.36 . Student learning attitudes in handling hoaxes get an average value of 2.99 while the control class is only 2.61. Although both of them have proper criteria, blended learning can also encourage participants to make the best use of face-to-face contact in developing knowledge. Thus, students are able to identify hoax news and implement it by providing information through social media to the public. The implications of this study provide convenience for lecturers in conducting learning strategies on learning ethical communication and new media for handling hoaxes.
\end{abstract}

Keywords - Communication studies, hoax, blended learning, higher education.

\section{Introduction}

An effective learning process will make students active during the learning process [1]. Active learning can be done to manage classes using various methods [2]. Lecturers who are able to apply multiple methods of knowledge that are creative, varied and more focused in developing their students will make students more active in the learning 
process [3]. Learning activities are activities carried out in the learning process between the teacher and students in order to achieve learning goals [4]. Therefore, student activities in the learning process are essential. So, this learning activity is important to involve all components in the education process, especially the use of information technology as a medium in learning [5]. The emergence of technology in the field of information and communication has brought enormous benefits to human life, including the world of education hugely benefited from the progress in the field of technology because of its extraordinary benefits [6]. One that gets significant attention, along with the development of Information Technology is a learning system that develops multimedia-based learning, both online and offline [7]. In real terms, the form of information and communication technology development that has been implemented in the world of education is electronic learning, commonly abbreviated as e-learning [8]. Optimizing the integration of existing oral communication in face-to-face learning with written communication in online learning is the basic concept of Blended Learning model [9]. The use of e-learning is an example of flexible learning in the Blended Learning method. The application of this model can improve mutuality and the quality of education [10]. This learning can show a more significant difference in terms of motivation, interest, and student learning outcomes compared to other methods, especially methods of indirect learning [11]. Blended Learning method successfully became a trend and is widely used in leading universities in the world [12].

In higher education, learning strategies are as important as planning [13]. Learning management strategy is still conceptual in nature, specific learning methods are used [14]. That is connected with the communication activities as a result of social relations [15]. According to Elboubekri [16], the intercultural communicative competence in Morocco University students should have information and technology attitude. Abdalla, et al. [17] explained to exercise students position they need a blended learning approach to teaching communication systems. Communication can be done directly or indirectly, using a variety of available of blended learning to balancing the best of both worlds for students [18]. For this reason, this study aims to describe the learning strategy management of communication studies through blended learning in higher education.

\section{$2 \quad$ Blended Learning and Communication Studies}

According to Perera, et al. [19] teacher of urban education institutions often explore new methods of teaching using the innovative techno-pedagogical approach. One of that approach is Blended learning to enables the use of online learning resources, especially web-based ones, without leaving face-to-face activities [20]. The goal of students' understanding of the learning material in the blended learning method is to help students develop better in the learning process. Tupe [21] explained the effectiveness of blended learning program could enhancing entrepreneurial skill among women in Maharashtra. On the other hand, blended learning also provides realistic, practical opportunities for lecturers and students to learn independently, be useful, and continues to grow [22]. Blended learning describes an opportunity that integrates innovation and the benefits 
of technology in online learning. Meanwhile, Fleischmann [23] explains blended learning as learning that combines synchronous and asynchronous learning settings precisely in order to achieve learning objectives. In addition, Arellano et al. [24] shown that emotions, motivation and cognitive-metacognitive strategies in blended learning are closely correlated with student performance. Blended learning by constructive approach (BLCA) consists of two terms, blended learning and helpful approach [25]. According to Carlsson, et al. [26] blended learning enhanced competence of students and also active involvement there in the classroom. The aspects that are combined in blended learning not only combine face-to-face education and online learning, but can also take any form, such as methods, media, resources, environment or learning strategies [27]. Based on the proportion of content delivered online Elyakim, et al. [28] provide a precise categorization of blended learning, conventional learning, web facilitated, and online learning.

Blended learning can be used independently by students; the existence of a lecture becomes very meaningful as an adult whose function is to provide support and assist students in the learning process [29]. In other words, the face-to-face process is essential and should not be abandoned in learning. Therefore, the blended learning model is the method of face to face learning with e-learning in an integrative and systematic way would make the learning process more meaningful [30]. E-learning is able to improve the learning experience because students can learn anywhere as long as they are connected to the internet. Blended learning is a flexible approach to designing programs that support a mixture of different times and places for learning [31]. According to Cottle and Glover [32], blended learning may involve significant amounts of faculty time for creating the course. Through blended learning, the conventional teaching and learning process would be assisted with e-learning which in this case, stands on the information technology infrastructure [33]. In ethic communication on communication studies, blended learning used to find the impact of the influence of technological advances gives rise to hoax news [34]. Hoaxes usually arise when an issue sticks to the surface, but many things have not been revealed or become a question mark [35]. Deception is the impact of changing the function of social media from friendship media and sharing the means of conveying political opinions and commenting on the views of others [36]. For this reason, blended learning becomes important to provide education that combines the application of traditional learning in the classroom with online learning that utilizes information technology [19]. Therefore, blended learning can accommodate broad technological developments without face-to-face learning in class by combining face-to-face learning with e-learning [37]. Hoax aims to create public opinion, lead opinion, shape perception, also to have fun that tests the intelligence and accuracy of internet and social media users [38]. The education sector has an essential role in providing communication through blended learning related to the spread of hoaxes[39]. 


\section{$3 \quad$ Methodology}

This study uses a quasi-experimental method with a non-equivalent control group research design [40]. This design uses two groups, namely the experimental group and the control group. This research design was used because, in the selection of samples, it was carried out randomly from the existing class of the study population [41]. Elearning learning in this study is a learning activity that conveys teaching materials, and the learning process is carried out by using an internet network in the form of an online site utilizing an internet browser device [42]. While the Learning management system is a web application that supports the learning process [43], which is a web application to integrate many functions in supporting the learning process, in this study, the LMS used is the platform http://fis.unj.ac.id/elearning/jarnik/course/index.php?categoryid=7. and Mobile Application. The subject of the study was the 2019 Communication Science Student, Faculty of Social Sciences, Jakarta State University. Of the 82 students divided into three classes, namely full e-learning, blended e-learning and conventional classes. This research collaborates with ethics communication lecturer. Thus, the sample used in this study was 42 students for blended e-learning classes and 40 students for conventional classes. E-learning learning that has been designed and published online is then implemented on hoax handling material [44]. After carrying out the implementation, the questionnaire was filled in to find out the students' attitudes towards e-learning learning.

Learning Management System (LMS) useful for the ethical communication course for supplementary materials supporting [45]. In general, the age of students in the first, second, third or fourth semester ranges from 18 to 21 years. Based on the current age of students who should take ethical communication courses come from native digital circles (people born when digital technology has developed) [46]. Character analysis of student attitudes towards the course helps instructional developers to choose the right learning strategy. Students' conceptual abilities are very diverse in relation to topics, for example, direct experience of assignments, media use [47]. Researchers conducted posttest and pretest tests on the mastery of the concept of handling hoaxes with using the gain score calculation developed by Hake in [48]. With the criteria for N-gain value:

Table 1. N-Gain Criteria

\begin{tabular}{|c|c|}
\hline Acquisition of N-Gain & Criteria \\
\hline $\mathrm{N}$-gain $>0,70$ & High \\
\hline $0,30 \leq \mathrm{N}-$ gain $\leq 0,70$ & Middle \\
\hline $\mathrm{N}$-gain $<0,30$ & Low \\
\hline
\end{tabular}

*Source: Mellenbergh [48]

Then, analysis of student learning attitude data uses descriptive analysis through a Likert scale [49]. The statement submitted in the questionnaire includes an attitude indicator. The instrument uses 4 Likert scales consisting of; 1) strongly disagree; 2) disagree; 3) agree, and 4) strongly agree. There are 11 statements in the questionnaire relating to student learning attitudes on the cognitive component. As a reference for data analysis and description, rating scales are made with the following criteria and 
predicates; 1) 1.00 - 1.50 (very less); 2) 1,51 - 2,50 (less); 3) 2,51 - 3,50 (good); and 4) $3.51-4.00$ (very good). Analysis of the collected data was performed using descriptive statistical data analysis techniques. Analysis of the collected data was carried out using descriptive statistical data analysis techniques. The learning process is carried out for 90 minutes. The contents of the material provided are detecting hoaxes and methods for identifying news stories and hoaxes. To find out the response to the learning process with e-learning is done by interviewing 20 students who were chosen randomly. Researchers also conducted interviews with two ethical communication lecturers. The interview was conducted for 45 minutes after the learning process.

\section{$4 \quad$ Results}

The analysis of student learning attitude data uses descriptive analysis through a Likert scale [49]. The statement submitted in the questionnaire includes an attitude indicator. The instrument uses 4 Likert scales consisting of; 1) strongly disagree; 2) disagree; 3 ) agree, and 4) strongly agree. The data taken in this study are cognitive learning outcomes on the theme of handling hoaxes with sub-themes of techniques and methods for identifying factual news and hoaxes. The study was conducted during three meetings for the experimental class and one meeting for the control class. Each class carried out learning with an allocation of time 3 x 90 minutes. Data were collected twice (pretest and posttest) for each class. In the learning process, the experimental class and the control class both use a scientific approach, but the experimental class is treated using a blended learning model, while the control class does not use a blended learning model.

\subsection{Control class}

The conventional learning process in the control class is done with a lecture and discussion learning model. The lecturer gives hoax handling material through power points. After the lecturer explained the material handling hoax, students were divided into four groups. Each group discusses the hoax. The first meeting up to the third, the lecturer only used PowerPoint, video and pictures as learning media.

\subsection{Experimental class}

In the experimental class, the first lecturer meeting uses a blended learning model. Students are directed to open their laptops to access the website http://fis.unj.ac.id/elearning/jarnik/course/index.php?categoryid=7. Then, students join by registering using email. Furthermore, students open ethics communication courses and open material handling hoaxes. After that, students are given the opportunity to explain the concept of material and examples of hoaxes. At the second meeting, students were invited to open the application via smartphone by scanning barcodes. After that, do the instructions on the smartphone layer. 


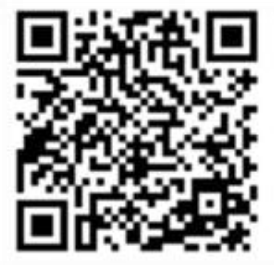

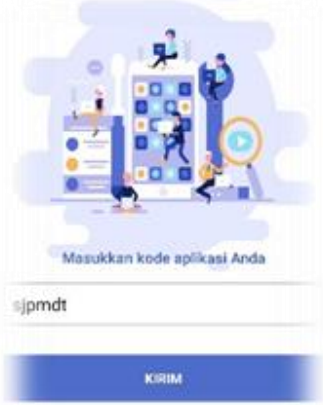

(b)

Fig. 1. Mobile Application Barcode

Then, through the Anti Hoax application the image will appear as below:

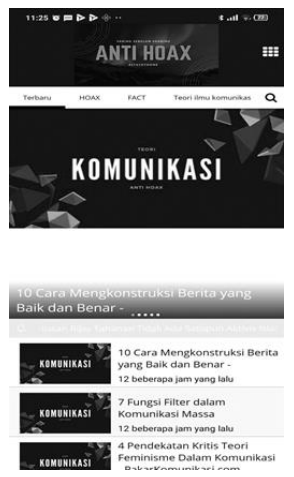

(a)
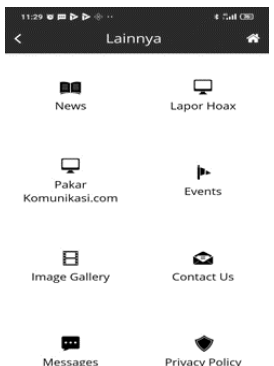

(b)

Fig. 2. Mobile Application Handling Hoax

Students can access information related to anti-hoaxes through applications to identify forms of hoax news. In the application, students are invited to view the news through social media and online news. Then, identify whether the news is included in the hoax. Then they can click Report Hoax. Students are also invited to socialize antihoaxes through social media. At the third meeting, the lecturer gave a task related to handling hoaxes by making videos uploaded through http://fis.unj.ac.id/elearning/jarnik/course/index.php?categoryid=7. 
Then do the assignment online through Google form. To improve student ethics communication, lecturers provide opportunities for students to present the results of their videos in class. Both of the above processes were carried out after the researchers gave a pretest to 82 students. After the learning process lasts for three meetings, the researcher provides a posttest to students. The following are the results of the student pretest and posttest scores:

Table 2. Student Pretest and Posttest scores in the Experiment class

\begin{tabular}{|c|c|c|c|c|c|}
\hline \multirow{2}{*}{ No } & \multirow{2}{*}{ Score } & \multicolumn{4}{|c|}{ Class } \\
\cline { 3 - 7 } & & \multicolumn{2}{|c|}{ Pretest } & \multicolumn{2}{c|}{ Posttest } \\
\cline { 3 - 7 } & & $\boldsymbol{F}$ & Percentage & $\boldsymbol{F}$ & Percentage \\
\hline 1 & $>70$ & 7 & $16,7 \%$ & 36 & $85,7 \%$ \\
\hline 2 & $\leq 0,70$ & 35 & $83,3 \%$ & 6 & $14,3 \%$ \\
\hline Amount & 42 & $100 \%$ & 42 & $100 \%$ \\
\hline \multicolumn{2}{|r|}{55,93} & \multicolumn{3}{c}{81,85} \\
\hline
\end{tabular}

Table 2 shows the average pretest value of the experimental class was 55.93, and the posttest value was 81.85 . After conducting research in the experimental class with the treatment given during the learning process, they are then conducting research in the control class without using a blended learning model. The following is the data of the pretest and posttest learning outcomes in the control class.

Table 3. Student Pretest and Posttest scores in the Control class

\begin{tabular}{|c|c|c|c|c|c|}
\hline \multirow{2}{*}{ No } & \multirow{2}{*}{ Score } & \multicolumn{4}{|c|}{ Class } \\
\cline { 3 - 6 } & & \multicolumn{2}{|c|}{ Pretest } & \multicolumn{2}{c|}{ Posttest } \\
\cline { 3 - 6 } & & $\boldsymbol{F}$ & Percentage & $\boldsymbol{F}$ & Percentage \\
\hline 1 & $>70$ & 10 & $23,8 \%$ & 23 & $54,8 \%$ \\
\hline 2 & $\leq 0,70$ & 32 & $76,2 \%$ & 19 & $45,2 \%$ \\
\hline Amount & 42 & $100 \%$ & 42 & $100 \%$ \\
\hline \multicolumn{2}{|l|}{57,22} & \multicolumn{2}{c}{71,11} \\
\hline
\end{tabular}

Source: Research Data

Table 3 shows the average value of the control class pretest was 57.27, and the posttest value was 71.11. After knowing the grades in the two classes, the next step is to calculate using the data from the pretest and posttest to find out the increase in knowledge (N-gain). Following is the classification of $\mathrm{N}$-Gain values between the experimental class and the control class after participating in the learning. The N-Gain classification can be seen in the following table. 
Table 4. Grouping of N-Gain Value in Communication Science Class 2019 A (Experiment) and Communication Science Class 2019 B (Control)

\begin{tabular}{|c|c|c|c|c|}
\hline \multirow{2}{*}{ Category } & \multicolumn{2}{|c|}{ Frequency } & \multicolumn{2}{c|}{ N-Gain Average } \\
\cline { 2 - 3 } & $\boldsymbol{A}$ & $\boldsymbol{B}$ & $\boldsymbol{A}$ & \multirow{2}{*}{0} \\
\hline High & 25 & 18 & \multirow{2}{*}{0,56} & 0,36 \\
\hline Middle & 12 & 11 & & \\
\hline Low & 5 & 13 & \\
\hline
\end{tabular}

Table 4 shows the N-Gain of the experimental class students who were in the high category of 25 students, 12 students, and five students low. While the control class is classified in the high category of 18 students, while 11 Pretest Posttest students are students, and 13 students are low. The average N-Gain in both the experimental class and the control class falls into the medium category. The average results of the N-Gain experimental class were higher at 0.56 compared to the control class at 0.36 . The difference in N-Gain between the experimental class and the control class is 0.20 .

\subsection{Student learning attitudes in handling hoaxes}

The following is the data obtained related to student learning attitudes in handling hoaxes. Learning attitude in question includes cognitive components related to the material handling hoaxes in ethical communication.

Table 5. The Average Value of Students Learning Attitudes in Handling Hoax

\begin{tabular}{|c|l|c|c|c|c|}
\hline No & \multicolumn{1}{|c|}{ Indicators of Learning Attitudes } & Experiment Class & \multicolumn{2}{c|}{ Control Class } \\
\cline { 3 - 5 } & & Score & Criteria & Score & Criteria \\
\hline 1 & Hoax arises due to unclear information & 2,85 & Good & 2,54 & Good \\
\hline 2 & $\begin{array}{l}\text { The lack of social media literacy led to the emergence } \\
\text { of hoax reporting }\end{array}$ & 2,95 & Good & 2,85 & Good \\
\hline 3 & $\begin{array}{l}\text { Hoax circulation is indeed more natural to develop on } \\
\text { the internet and social media. }\end{array}$ & 3,07 & Good & 3,00 & Good \\
\hline 4 & $\begin{array}{l}\text { News hoaxes have been made in a way that resembles } \\
\text { the original news, supplemented with data as if it } \\
\text { were a fact }\end{array}$ & 2,84 & Good & 2,54 & Good \\
\hline 5 & $\begin{array}{l}\text { Communication ethics includes all values and norms } \\
\text { that become the standard and human reference in } \\
\text { communicating with others }\end{array}$ & 2,97 & Good & 2,77 & Good \\
\hline 6 & $\begin{array}{l}\text { Communication ethics evaluate good and bad com- } \\
\text { munication actions based on applicable standards. }\end{array}$ & 2,92 & Good & 2,85 & Good \\
\hline 7 & $\begin{array}{l}\text { To do this search, you can use images.google.com, by } \\
\text { dragging and dropping to upload photos }\end{array}$ & 3,10 & Good & 2,20 & Enough \\
\hline 8 & Look at the hoax news site & 3,17 & Good & 2,92 & Good \\
\hline 9 & Checking the truth of the news through the internet & 3,00 & Good & 2,54 & Good \\
\hline 10 & Report hoax news through the anti-hoax app & 3,17 & Good & 2,20 & Enough \\
\hline 11 & Socialising hoax news through social media & 2,92 & Good & 2,40 & Enough \\
\hline & & 2,99 & Good & 2,61 & Good \\
\hline
\end{tabular}


Table 5. shows the average value of attitudes related to the material handling hoaxes. The total average and predicate obtained in almost all aspects included in the good predicate. There are some aspects that get an average value below the total average value overall and especially in aspects that get a predicate less. The control class shows that they are less able to do hoax news removal using images.google.com. In addition, students in the control class had low average scores on reporting hoax news through an anti-hoax application that scored below an average total of 2.61. The experimental class and the control class show that understanding hoax circulation is indeed easier to develop on the internet and social media with values above the average total of 2.99 and 2.61. The lower average value of the control class than the experimental class illustrates that there is the ineffectiveness of learning using traditional models.

\section{Discussion}

Hypothesis testing in this study was carried out using an independent sample t-test formula to determine the effect of the blended learning model on student learning outcomes related to hoax handling. The results of calculations using the formula independent sample t-test are known that $t_{\text {count }}>t_{\text {table }}=3.396>2,000$. That is means Ha is accepted. There is a positive and significant influence on the blended learning model on the results of the experimental class and control class analysis shows a difference in student learning outcomes. Before being treated, it is known that the average value of the pretest in the experimental class is lower than the control class, but the comparison of the values of the two classes is not too far away. The average pretest value of the experiment was 55.93, and the control class was 57.22. The pretest value data of the experimental class and the control class were tested for normality by the squared formula. The results of the pretest normality test of the experimental class manually obtained data for $\mathrm{X}_{2}$ count $<\mathrm{X}_{2}$ table $=9,483<\mathrm{X}_{2}$ table $=7.164<1.93$ means that $\mathrm{Ha}$ is accepted because the data has the same variant. Both groups are normally distributed and homogeneous, meaning that both groups have the same initial ability. Based on the pretest values above, then the two classes were given different treatments during the learning process. In line with Rafiola et al. [30] the experimental class uses the blended learning model, while the control class applies conventional learning affected to increased students on handling hoax.

The finding of this study showed the blended learning model is going well [31]. However, there are still shortcomings as not all students can participate in online learning due to the lack of facilities owned by students. At the end of the lesson, both classes were given a posttest to test the ability of students to understand the material that had been learned after being treated. The posttest results of the experimental class have an average higher than the control class that is equal to 81.85 in the experimental class and 71.77 in the control class. Posttest normality test results in the experimental class using the chi-square formula of $\mathrm{X}_{2}$ count $\left\langle\mathrm{F}_{\text {table }}=1.22\right.$ table $\left.=3.396\right\rangle 2,000$, means Ha is accepted. This meaning that there is a positive and significant influence on the blended learning model on student learning outcomes hoax handling themes in the eyes lecture on ethics communication. This research is relevant to research conducted according to 
Cottle and Glover [32], Elyakim et al. [28], and also Yeou [39]. The results of the hypothesis test, which also states that there is a positive and significant influence on the blended learning model on student learning outcomes, means that the hypothesis proposed by the researcher is acceptable. These results show that blended learning enhanced teaching and learning in communication ethics for students in higher education[42].

In addition, researchers conducted interviews with 20 students after the learning process took place. Researchers also collaborated with ethical communication lecturers. In this study, students written A1 - A20. Questions raised by students were 10. These questions were related to the use of blended learning in the hoax handling learning process. "... the use of blended learning through applications and websites makes it easy for me to understand hoax handling" (A1, 2020). In ethical communication, it takes students' understanding of hoax handling. This becomes something interesting when I can immediately identify hoax news through an application on my cellphone (A3, 2020). "The learning process using blended learning makes it easy for me to understand hoax identification methods" (A5, 2020). As students, it is important for us to know how to handle hoaxes via the internet (A6, 2020). An exciting learning process, the availability of informative material makes me motivated in learning hoax handling (A8, 2020). Lecturers not only become centres, but students are invited to be active in the process of learning ethical communication (A13, 2020). The blended learning model has the aim to facilitate learning by providing a variety of learning media with regard to the characteristics of students in learning (Lecture 1, 2020). This learning can also encourage participants to make the best use of face-to-face contact in developing knowledge (Lecture, 2).

Based on the results of the interview above, complete the follow-up of blended learning can be done offline and online. Online learning is effectively carried out if there are students who are unable to attend, with the use of online media it is expected that students will still be able to follow the subject matter [15]. Blended learning is very effective and efficient learning to improve students' abilities to be fun, greater student interest in learning with a diverse learning environment [12]. Blended learning offers better learning, whether separate or in groups as well as the same or different time.

The action research findings are in line with several research results which show that the application of learning strategies for handling hoax subjects through Blended Learning has been proven to improve student learning outcomes [9]. According to Suartama et al., [10] it must be recognised that the effectiveness of learning strategies through blended learning in improving student learning outcomes is strongly influenced by several factors between lecturers and the availability of learning media. In order to be effective in applying learning strategies through Blended Learning, lecturers must truly understand the nature, principles and procedures. Blended learning requires adequate learning media in accordance with the subject matter to be taught. Blended learning is believed to be able to improve student learning outcomes and at the same time, improve the learning process capable, if applied correctly in planning and implementation[5]. This is indicated in the posttest results of the experimental class, which showed an increase from 55.93 to 81.85 . Blended learning encourages students to use a deep learning approach seems like Nicol, et al. [6] research finding. In this case, students view the 
handling of hoaxes as a process of the meaning of concepts, facts learned related to the implementation of ethical communication in the digital age.

Blended learning allows students to get information from various sources through the tools used. Therefore, blended learning can be one alternative to facilitate diverse student learning styles. Blended learning tends to be flexible and can take place outdoors [13]. Blended learning can function as a compliment. In other words, blended learning can be used as a complement to learning activities in the classroom in which implementation can be done outside the university [14]. Blended learning activities are also in accordance with the character of the material in the eye handling hoax [50]. The characteristics of the material being learned are identifying various hoax news and being able to inform it through social media. Students can make more use of learning modalities to utilise information technology well [51]. In the process of learning, hoax handling learning practices and auditive-visual learning styles are needed to be facilitated here. Student learning attitude use of web-based technology as a source of learning and learning media is one of blended learning [24].

Student learning styles have become increasingly facilitated according to the characteristics of each student. The ease of accessing information can be utilised in learning activities [52]. This convenience is supported by the availability of various tools resulting from technology. These tools need to be used by teachers in organised learning so that they can adapt to the habits and preferences of students. Utilisation in accessing educational information can make it easier for students to support their studies and an Android smartphone is now not only a mere communication tool but has become a learning tool that is now present in student life [53]. The results of this study support the understanding that smartphones can indeed be used as media in learning activities [54-55]. Blended learning is considered appropriate for today's students. Students often use smartphones to access information so that it is appropriate when the material is delivered to students through links that can be accessed by students. Thus, it is hoped that learning activities in the classroom can be more effective.

\section{Conclusion}

Blended learning is a learning model that can increase attractiveness in the face-toface learning process and is very suitable to be applied in the 21 st era. Blended learning can accommodate broad technological developments without face-to-face learning in class by combining face-to-face learning with e-learning. Blended learning allows students to continue learning and follow the learning process. This can be an opportunity for the success of lecturers and students in learning. Blended learning also helps lecturers prepare students to create a learning environment in accordance with the learning styles of each student and can help students face challenges in the future. Based on the results of data analysis and discussion in this study, it can be concluded that there is a positive and significant influence on the blended learning model on learning outcomes of communication science students 2019, Faculty of Social Sciences, Jakarta State University. The results of testing the hypothesis using the t-test formula obtained data $t_{\text {count }}$ of 3.396, while $t_{\text {table }}$ of 2,000, the comparison shows $(3.396>2,000)$ means Ha is 
accepted. The average $\mathrm{N}-$ Gain of the experimental class was 0.56 , while the average $\mathrm{N}$ Gain of the control class was 0.36 , the difference between the N-Gain of the two classes was 0.20 . Thus, Blended learning is an alternative solution to overcome the weaknesses of online learning and face-to-face learning to produce a series of effective, efficient and enjoyable learning for students by not discarding old learning theories. Technology in Indonesia is not evenly distributed due to the vast territory and limited resources. The government must invest technology in each region and provide training to lecturers so that they can improve the quality of Indonesian education and can apply Blended learning models in Indonesia to accelerate and simplify the learning process. Then, website network development is needed in every tertiary institution in Indonesia

\section{$7 \quad$ References}

[1] J. Dunlosky, K. A. Rawson, E. J. Marsh, M. J. Nathan, and D. T. Willingham, "Improving students' learning with effective learning techniques: Promising directions from cognitive and educational psychology," Psychol. Sci. Public Interes. Suppl., vol. 14, no. 1, pp. 4-58, 2013. https://doi.org/10.1177/1529100612453266

[2] S. H. K. Kang, "Spaced Repetition Promotes Efficient and Effective Learning: Policy Implications for Instruction," Policy Insights from Behav. Brain Sci., vol. 3, no. 1, pp. 12-19, 2016. https://doi.org/10.1177/2372732215624708

[3] S. Kumar, L. McLean, L. Nash, and K. Trigwell, "Incorporating active learning in psychiatry education," Australas. Psychiatry, vol. 25, no. 3, pp. 304-309, 2017. https://doi.org/10.1177 $\underline{1039856217689912}$

[4] S. Papadakis, M. Kalogiannakis, and N. Zaranis, "Comparing Tablets and PCs in teaching Mathematics: An attempt to improve Mathematics Competence in Early Childhood Education," Presch. Prim. Educ., vol. 4, no. 2, p. 241, 2016. P. Dorouka, St, Papadakis, and M. Kalogiannakis, M, "Tablets and apps for promoting robotics, mathematics, STEM education and literacy in early childhood education", International Journal of Mobile Learning and Organisation, vol. 14, no. 2, pp. 255-274, 2020. https://doi.org/10.1504 /IJMLO.2020.10026334

[5] L. McCoy, R. K. Pettit, C. Kellar, and C. Morgan, "Tracking Active Learning in the Medical School Curriculum: A Learning-Centered Approach," J. Med. Educ. Curric. Dev., vol. 5, p. 2382120518765135, 2018. https://doi.org/10.1177/2382120518765135

[6] A. A. M. Nicol, S. M. Owens, S. S. C. L. Le Coze, A. MacIntyre, and C. Eastwood, "Comparison of high-technology active learning and low-technology active learning classrooms," Act. Learn. High. Educ., vol. 19, no. 3, pp. 253-265, 2018. https://doi.org/10.1177 /1469787417731176

[7] N. Singhal, H. Gupta, and G. Mittal, "Importance-performance Analysis to Identify Effective Learning Approaches for Sustainability in an Indian," Vision, vol. 22, no. 3, pp. 276283, 2018. https://doi.org/10.1177/0972262918785963

[8] C. Willard-Holt, J. Weber, K. L. Morrison, and J. Horgan, "Twice-Exceptional Learners' Perspectives on Effective Learning Strategies," Gift. Child Q., vol. 57, no. 4, pp. 247-262, 2013. https://doi.org/10.1177/0016986213501076

[9] W. Banyen, C. Viriyavejakul, and T. Ratanaolarn, "A blended learning model for learning achievement enhancement of thai undergraduate students," Int. J. Emerg. Technol. Learn., vol. 11, no. 4, pp. 48-55, 2016. https://doi.org/10.3991/ijet.v11i04.5325 
[10] I. K. Suartama, P. Setyosari, Sulthoni, and S. Ulfa, "Development of an instructional design model for mobile blended learning in higher education," Int. J. Emerg. Technol. Learn., vol. 14, no. 16, pp. 4-22, 2019. https://doi.org/10.3991/ijet.v14i16.10633

[11] K. Smith and P. Horvath, "Active learning strategies for phenotypic profiling of high-content screens," J. Biomol. Screen., vol. 19, no. 5, pp. 685-695, 2014. https://doi.org/10.1177 1087057114527313

[12] E. Ike and I. B. Okechukwu, "Effective Learning Systems through Blended Teaching Modules in Adult Secondary Education Systems in Developing Nations: Need for Partnership," J. Adult Contin. Educ., vol. 21, no. 1, pp. 18-30, 2015. https://doi.org/10.7227 /JACE. 21.1 .3

[13] S. Dakduk, Z. Santalla-Banderali, and D. van der Woude, "Acceptance of Blended Learning in Executive Education," SAGE Open, vol. 8, no. 3, 2018. https://doi.org/10.1177 I2158244018800647

[14] N. J. Hulbert-Williams, "Facilitating Collaborative Learning Using Online Wikis: Evaluation of Their Application Within Postgraduate Psychology Teaching," Psychol. Learn. Teach., vol. 9, no. 1, pp. 45-51, 2010. https://doi.org/10.2304/plat.2010.9.1.45

[15] S. Timcke, "Communication studies at the crossroads: What do we stand for?," Int. Commun. Gaz., vol. 78, no. 7, pp. 726-730, 2016. https://doi.org/10.1177 1748048516655714

[16] A. Elboubekri, "The Intercultural Communicative Competence and Digital Education," J. Educ. Technol. Syst., vol. 45, no. 4, pp. 520-545, 2017. https://doi.org/10.1177 $\underline{10047239516670994}$

[17] H. Abdalla, A. J. Soares Martins, D. Garrosini, and L. F. Maolinaro, "Experiences of applying a 'blended' learning approach to client-based student projects," Int. J. Electr. Eng. Educ., vol. 49, no. 2, pp. 170-176, 2012. https://doi.org/10.7227/IJEEE.49.2.4

[18] K. McKenna, K. Gupta, L. Kaiser, T. Lopes, and J. Zarestky, "Blended Learning: Balancing the Best of Both Worlds for Adult Learners," Adult Learn., vol. 20, no. 10, 2019. https://doi.org/10.1177/1045159519891997

[19] C. J. Perera, Z. Zainuddin, C. Y. Piaw, K. S. L. Cheah, and D. Asirvatham, "The Pedagogical Frontiers of Urban Higher Education: Blended Learning and Co-Lecturing," Educ. Urban Soc., 2020. https://doi.org/10.1177/0013124519894966

[20] R. W. Rix, "Blended learning: Perspectives on mixing online and offline communities of enquiry," E-Learning Digit. Media, vol. 8, no. 4, pp. 423-433, 2011. https://doi.org/10.2304/elea.2011.8.4.423

[21] N. Tupe, "A Study of the Effectiveness of Blended Learning Program for Enhancing Entrepreneurial Skills Among Women in Maharashtra," J. Educ., 2020. https://doi.org/10.1177 /0022057420903257

[22] F. A. Taylor, E. Nelson, K. Delfino, and H. Han, "A Blended Approach to Learning in an Obstetrics and Gynecology Residency Program: Proof of Concept," J. Med. Educ. Curric. Dev., vol. 2, 2015. https://doi.org/10.4137/JMECD.S32063

[23] K. Fleischmann, "Hands-on versus virtual: Reshaping the design classroom with blended learning," Arts Humanit. High. Educ., 2020. https://doi.org/10.1177/ $\underline{1474022220906393}$

[24] A. Ramirez-Arellano, J. Bory-Reyes, and L. M. Hernández-Simón, "Emotions, Motivation, Cognitive-Metacognitive Strategies, and Behavior as Predictors of Learning Performance in Blended Learning," J. Educ. Comput. Res., vol. 57, no. 2, pp. 491-512, 2019. https://doi.org/10.1177/0735633117753935 
[25] A. Poncela, "A blended learning approach for an electronic instrumentation course," Int. J. Electr. Eng. Educ., vol. 50, no. 1, pp. 1-18, 2013. https://doi.org/10.7227/IJEEE.50.1.1

[26] Õ. Umb Carlsson, N. Källberg, and B. Wadensten, "Blended Learning Among Elderly Care Managers Inspires Projects That Take Older People's Perspectivesintoo Account," Home Heal. Care Manag. Pract., vol. 27, no. 3, pp. 142-149, 2015. https://doi.org/10.1177 $\underline{1084822314563331}$

[27] U. Ojiako, M. Chipulu, A. Marshall, M. J. Ashleigh, and T. Williams, "Project Management Learning: A Comparative Study Between Engineering Students' Experiences in South Africa and the United Kingdom," Proj. Manag. J., vol. 46, no. 4, pp. 47-62, 2015. https://doi.org/10.1002/pmj.21510

[28] N. Elyakim, I. Reychav, B. Offir, and R. McHaney, "Perceptions of Transactional Distance in Blended Learning Using Location-Based Mobile Devices," J. Educ. Comput. Res., vol. 57, no. 1, pp. 131-169, 2019. https://doi.org/10.1177/0735633117746169

[29] M. S. H. Khan, B. O. Abdou, J. Kettunen, and S. Gregory, "A phenomenographic research study of students' conceptions of mobile learning: An example from higher education," SAGE Open, vol. 9, no. 3, 2019. https://doi.org/10.1177/2158244019861457

[30] R. H. Rafiola, P. Setyosari, C. L. Radjah, and M. Ramli, "The Effect of Learning Motivation, Self-Efficacy, and Blended Learning on Students' Achievement in The Industrial Revolution 4.0," Int. J. Emerg. Technol. Learn., vol. 15, no. 08, p. 71, 2020. https://doi.org/10.3991 lijet.v15i08.12525

[31] S. Yusoff, R. Yusoff, and N. H. Md Noh, "Blended Learning Approach for Less Proficient Students," SAGE Open, vol. 7, no. 3, pp. 1-8, 2017. https://doi.org/10.1177 I2158244017723051

[32] N. R. Cottle and R. J. Glover, "Teaching Human Development:A Case for Blended Learning," Teach. Psychol., vol. 38, no. 3, pp. 205-208, 2011. https://doi.org/10.1177 /0098628311411900

[33] L. L. Hsu, "Blended learning in ethics education: A survey of nursing students," Nurs. Ethics, vol. 18, no. 3, pp. 418-430, 2011. https://doi.org/10.1177/0969733011398097

[34] M. Hynes, S. Sharpe, and A. Greig, "Appearing True in the social sciences: Reflections on an academic Hoax," J. Sociol., vol. 48, no. 3, pp. 287-303, 2012. https://doi.org/10.1177/1440783311413487

[35] P. B. Thompson, "Ethics and Risk Communication," Sci. Commun., vol. 34, no. 5, pp. 618641, 2012. https://doi.org/10.1177/1075547012459177

[36] S. R. Veil, T. L. Sellnow, and E. L. Petrun, "Hoaxes and the Paradoxical Challenges of Restoring Legitimacy: Dominos' Response to Its YouTube Crisis," Manag. Commun. Q., vol. 26, no. 2, pp. 322-345, 2012. https://doi.org/10.1177/0893318911426685

[37] S. Papadakis, M. Kalogiannakis, E. Sifaki, and N. Vidakis, "Access moodle using smart mobile phones. A case study in a Greek University," in Inractivity, Game Creation, Design, Learning and Innovation, 229th ed., A. L. Brooks, E. Brooks, and N. Vidakis, Eds. Springer International Publishing, 2018, pp. 376-385. https://doi.org/10.1007/978-3-319-76908$\underline{0 \quad 36}$

[38] K. Park and H. Rim, "'Click First!': The Effects of Instant Activism Via a Hoax on Social Media," Soc. Media Soc., vol. 6, no. 2, 2020. https://doi.org/10.1177 /2056305120904706

[39] M. Yeou, "An Investigation of Students' Acceptance of Moodle in a Blended Learning Setting Using Technology Acceptance Model," J. Educ. Technol. Syst., vol. 44, no. 3, pp. 300318, 2016. https://doi.org/10.1177/0047239515618464 
[40] R. Gersten, L. S. Fuchs, D. Compton, M. Coyne, C. Greenwood, and M. S. Innocenti, "Quality indicators for group experimental and quasi-experimental research in special education," Except. Child., vol. 71, no. 2, pp. 149-164, 2005. https://doi.org/10.1177 /001440290507100202

[41] M. Gopalan, K. Rosinger, and J. Bin Ahn, "Use of Quasi-Experimental Research Designs in Education Research: Growth, Promise, and Challenges," Rev. Res. Educ., vol. 44, no. 1, pp. 218-243, 2020. https://doi.org/10.3102/0091732X20903302

[42] N. Milthorpe, R. Clarke, L. Fletcher, R. Moore, and H. Stark, "Blended English: Technology-enhanced teaching and learning in English literary studies," Arts Humanit. High. Educ., vol. 17, no. 3, pp. 345-365, 2018. https://doi.org/10.1177/1474022217722140

[43] M. Tubagus, S. Muslim, and Suriani, "Development of learning management system-based blended learning model using claroline in higher education," Int. J. Interact. Mob. Technol., vol. 14, no. 6, pp. 186-194, 2020. https://doi.org/10.3991/ijim.v14i06.13399

[44] D. Darmawan, E. Suryadi, and D. Wahyudin, "Smart digital for mobile communication through TVUPI streaming for higher education," Int. J. Interact. Mob. Technol., vol. 13, no. 5, pp. 30-46, 2019. https://doi.org/10.3991/ijim.v13i05.10286

[45] Y. Hanafi, N. M. Murtadho, A. Ikhsan, and T. N. Diyana, "Reinforcing public university student's worship education by developing and implementing mobile-learning management system in the ADDIE instructional design model," Int. J. Interact. Mob. Technol., vol. 14, no. 2, pp. 215-241, 2020. https://doi.org/10.3991/ijim.v14i02.11380

[46] A. J. Swart, "Student usage of a learning management system at an open distance learning institute: A case study in electrical engineering," Int. J. Electr. Eng. Educ., vol. 52, no. 2, pp. 142-154, 2015. https://doi.org/10.1177/0020720915575925

[47] T. Hameed and B. Swar, "Information systems acquisition decisions: Learning management system of SolBridge," J. Inf. Technol. Teach. Cases, vol. 6, no. 2, pp. 121-133, 2016. https://doi.org/10.1057/s41266-016-0006-y

[48] G. J. Mellenbergh, "A note on simple gain score precision," Appl. Psychol. Meas., vol. 23, no. 1, pp. 87-89, 1999. https://doi.org/10.1177/01466216990231007

[49] L. Retief, M. Potgieter, and M. Lutz, "The usefulness of the rasch model for the refinement of likert scale questionnaires," African J. Res. Math. Sci. Technol. Educ., vol. 17, no. 1-2, pp. 126-138, 2013. https://doi.org/10.1080/10288457.2013.828407

[50] C. Juditha, "Agenda Setting Penyebaran Hoaks di Media Sosial," J. Penelit. Komun., vol. 22, no. 2, pp. 155-168, 2019. https://doi.org/10.20422/jpk.v22i2.669

[51] J. Timmer, "Potential fcc actions against 'fake news': The news distortion policy and the broadcast hoax rule," Commun. Law Policy, vol. 24, no. 1, pp. 1-53, 2019. https://doi.org/10.1080/10811680.2018.1551020

[52] E. E. J. Thoonen, P. J. C. Sleegers, F. J. Oort, T. T. D. Peetsma, and F. P. Geijsel, "How to improve teaching practices: The role of teacher motivation, organizational factors, and leadership practices," Educ. Adm. Q., vol. 47, no. 3, pp. 496-536, 2011. https://doi.org/10.1177/0013161X11400185

[53] T. Fowler and D. Hagar, "Liking your union: Unions and new social media during election campaigns," Labor Stud. J., vol. 38, no. 3, pp. 201-228, 2013. https://doi.org/10.1177 /0160449X13506061

[54] St. Papadakis, M. Kalogiannakis, and N. Zaranis, "The effectiveness of computer and tablet assisted intervention in early childhood students' understanding of numbers. An empirical study conducted in Greece", Education and Information Technologies, vol. 23, no. 5, pp. 1849-1871, 2018. https://doi.org/10.1007/s10639-018-9693-7 
Paper-Learning Management Strategy of Communication Studies through Blended Learning in Higher..

[55] M. Kalogiannakis, G.M., Nirgianaki, and St. Papadakis, "Teaching magnetism to preschool children: The effectiveness of picture story reading", Early Childhood Education Journal, vol. 46, no. 5, pp. 535-546, 2018. https://doi.org/10.1007/s10643-017-0884-4

\section{Authors}

K.Y.S. Putri is a lecturer in Communication Studies at a Universitas Negeri Jakarta. She is also the Vice Dean of the academic section. She is also an Assistant Professor. She can be reached at kinkinsubarsa@unj.ac.id.

Zulhamri Bin Abdullah is a Professor in Universiti Putra Malaysia. He can be reached at zulhamri@upm.edu.my.

Elisabeth Nugrahaeni is a lecturer in Communication Studies at an Universitas Negeri Jakarta. She is also the Coordinator of Communication Studies. She is also an Associate Professor. She can be reached at enugrahaeni@unj.ac.id.

Rahmat Darmawan is a lecturer in Universitas Negeri Jakarta. He is also an Associate Professor. He can be reached at rahmat-darmawan@unj.ac.id.

Latifa is Undergraduated student of Communication Studies at a Universitas Negeri Jakarta.

Article submitted 2020-05-24. Resubmitted 2020-07-14. Final acceptance 2020-07-14. Final version published as submitted by the authors. 